\title{
PRZESŁANKI WYZNACZANIA SĘDZIÓW DO SKŁADU ORZEKAJĄCEGO TRYBUNAEU KONSTYTUCYJNEGO I KONSEKWENCJE ICH NARUSZENIA*
}

\section{WSTĘP}

Obowiąujące przepisy nie gwarantują wprost niezmienności składu orzekającego Trybunału Konstytucyjnego. Ustawy w oszczędny sposób reguluja wyznaczania sędziów do składu orzekającego przez Prezesa TK. Nie odnosza się też szerzej do przesłanek i konsekwencji zmiany składu w trakcie postępowania. Zaproponowana w doktrynie i orzecznictwie interpretacja nie dostarczyła zaś rozbudowanych kryteriów oceny dopuszczalności ewentualnej zmiany składu orzekającego ani skutków procesowych oraz materialnych takiej zmiany w postępowaniu przed TK ${ }^{1}$. Problematyka ta nie była dotąd wyczerpujaco omawiana $\mathrm{w}$ dogmatyce prawa konstytucyjnego. Zagadnienie to albo nie budziło większych kontrowersji, albo pozostawiono je (w zaufaniu i dobrej wierze) praktyce organu wewnętrznego TK, brak więc badań empirycznych. Skromność literatury w kontekście skali naruszeń prawa, które dotyczyły składu i zasad działania TK po 2015 r. $^{2}$, oraz wyników przeprowadzonych w 2017 r. analiz zarządzeń Prezesa TK ${ }^{3}$ skłaniają do przyjrzenia się wymogom kompetencji Prezesa TK do wyznaczenia sędziów do składu orzekającego TK ${ }^{4}$.

* Artykuł stanowi rozwinięcie badań przeprowadzonych w 2018 r. ramach projektu finansowanego ze środków Fundacji im. Stefana Batorego - Ziółkowski (2018): 107-135.

${ }^{1}$ Np. Czeszejko-Sochacki, Garlicki, Trzciński (1999).

${ }^{2}$ Szerzej o przyczynach i przebiegu kryzysu konstytucyjnego zapoczątkowanego w 2015 r. zob. Radziewicz, Tuleja (2017). Szerzej zaś o skali naruszeń zob. Sadurski (2019).

${ }^{3} \mathrm{~W}$ pierwszych dwóch miesiącach urzędowania w 2017 r. Julia Przyłębska wydała ponad 50 zarządzeń o zmianach w składach orzekających w sprawach przekazanych do merytorycznego rozpoznania oraz ponad 40 zarządzeń o zmianach składów orzekających w sprawach na etapie wstępnego rozpoznania skargi konstytucyjnej - Ziółkowski (2018): $110 \mathrm{n}$.

${ }^{4}$ Badania te wykazały bowiem, że istotna część zarządzeń została wydana bez wskazania podstawy prawnej kompetencji Prezesa TK do dokonania zmiany składu orzekającego oraz z naruszeniem kryterium: alfabetycznego, rodzaju i liczby spraw. Niemniej istotna część zarządzeń Prezesa TK została wydana bez wskazania jakichkolwiek okoliczności uzasadniających zmianę składu orzekającego TK albo z powołaniem się na - nieznane ustawie - „względy organizacyjne”. Celem części z nich było włączenie do składu TK osób nieuprawnionych do orzekania (tj. osób wybranych przez Sejm VIII kadencji na stanowiska sędziów TK legalnie obsadzone przez Sejm VII kadencji). Dokonane na początku tylko 2017 r. zmiany składów orzekających doprowadziły do takiego ukształtowania składów, że w $77 \%$ spraw funkcja przewodniczącego, a w $80 \%$ - funkcja 
Podjęcie zagadnienia uzasadniają też ustawowe zmiany zasad i reguł postępowania przed TK. Obowiązujące przez wiele lat, i niemalże bez istotniejszych merytorycznie zmian od wejścia w życie Konstytucji, przepisy ustawy o TK z 1997 r. ${ }^{5}$ zostały uchylone i zastapione ustawa o TK z 2015 r. ${ }^{6}$, która ustawodawca po roku uchylił mocą ustawy o TK z $2016 \mathrm{rr}^{7}$, wprowadzając niemalże identyczne przepisy o wyznaczaniu składu orzekającego. Te zaś po kilku miesiącach również utraciły moc obowiązującą i zostały zastapione przez ustawę o postępowaniu przed $\mathrm{TK}^{8}$.

Tezę artykułu można sprowadzić do następującego twierdzenia: zgodna z Konstytucją wykładnia przepisów ustawy o postępowaniu przed TK przemawia za przyjęciem zamkniętego katalogu kryteriów i okoliczności wyznaczenia sędziów i zmiany składu orzekającego TK. Wbrew dotychczasowej praktyce uważam, że: doniosłość, przedmiot oraz cel postępowania przed TK uzasadniają stanowisko o względnej niezmienności składu orzekającego. Ponadto w niniejszym artykule proponuję, by wymogi dotyczące czynności konwencjonalnej Prezesa TK (wyznaczenia sędziów do składu orzekającego) traktować jako formalizujące. Ponieważ ani przepisy regulujące postępowanie przed TK, ani utrwalone w orzecznictwie i nauce reguły postępowania nie odnoszą się wprost do proceduralnych i materialnych konsekwencji naruszenia owych wymogów, ich naruszenie przez Prezesa TK nie czyni jego czynności konwencjonalnej bezskuteczna albo nieważna. Nie wpływa też - w aktualnym stanie prawnym - na ocenę czynności, ważności lub skuteczności samego postępowania przed TK oraz orzeczenia o zgodności albo niezgodności normy z Konstytucja.

Niniejszy artykuł opiera się na (wynikającym z kolejnych przepisów ustawowych i silnie reprezentowanym $\mathrm{w}$ orzecznictwie konstytucyjnym) założeniu o autonomicznym charakterze postępowania przed TK względem postępowania cywilnego. W konsekwencji dla dalszych rozważań ograniczoną moc maja - popularne ostatnio w debacie publicznej - odesłania do przepisów Kodeksu postępowania cywilnego.

\section{WYZNACZENIE SĘDZIÓW DO SKŁADU ORZEKAJĄCEGO}

Wyznaczenie sędziów do składu orzekającego jest kompetencją Prezesa TK wynikającą wprost $\mathrm{z}$ art. 38 ust. 1 ustawy o postępowaniu przed TK. To przepis

sprawozdawcy powierzona została albo sędziemu TK wybranemu przez Sejm VIII kadencji, albo osobie wybranej przez Sejm VIII kadencji na stanowisko sędziego TK legalnie obsadzone przez Sejm VII kadencji. W 45 sprawach (na 49) do składu orzekającego włączono osoby wybrane przez Sejm VIII kadencji 2.12.2015 r. W bezprecedensowy sposób, wydawszy zarządzenia o zmianie składu orzekającego, Prezes TK doprowadził do tego, że 16 spraw zostało rozstrzygniętych nie w pełnym (wyznaczonym uprzednio) składzie TK, lecz w składzie pięciu (15 spraw) albo trzech sędziów TK (jedna sprawa) - zob. Ziółkowski (2018): 135.

${ }^{5}$ Ustawa z 1 sierpnia 1997 r. o Trybunale Konstytucyjnym, Dz. U. Nr 201, poz. 643 ze zm.

${ }^{6}$ Ustawa z 25 czerwca 2015 r. o Trybunale Konstytucyjnym, t.jedn.: Dz. U. 2016, poz. 293.

${ }^{7}$ Ustawa z 22 lipca 2016 r. o Trybunale Konstytucyjnym, Dz. U. poz. 1157.

${ }^{8}$ Ustawa z 30 listopada 2016 r. o organizacji i trybie postępowania przed Trybunałem Konstytucyjnym, Dz. U. poz. 2072. 
zrębowy kompetencyjny niezupełny ${ }^{9}$, wymagający uzupełnienia normatywnego. Ustawa zawiera również przepisy modyfikujące ${ }^{10}$. Konieczność dokonania w analizowanym przypadku stosownych uzupełnień przy rekonstrukcji normy kompetencyjnej nie oznacza, że przepis ten wyraża otwarty katalog kryteriów postępowania Prezesa TK przy wyznaczaniu sędziów do składu orzekającego. Uważam, że katalog ten ma charakter zamknięty i obejmuje wyznaczenie tylko w kolejności alfabetycznej i z uwzględnieniem rodzaju, liczby oraz kolejności wpływu spraw do TK. Przemawiają za tym następujace argumenty:

Po pierwsze, z uwagi na art. 197 Konstytucji kryteria wyznaczania członków składu orzekajaccego TK stanowia materię ustawowa. Z uwagi zaś na związek merytoryczny zasad wyznaczania składu z zachowaniem sprawiedliwości proceduralnej, zwłaszcza w sprawach inicjowanych pytaniem prawnym i skargą konstytucyjna, materię tę kwalifikuję jako objętą wyłącznością ustawy. Tym samym materia ta nie może być kształtowana ani przez akt wydany na podstawie upoważnienia ustawowego, ani - tym bardziej - czynnością konwencjonalną samego Prezesa TK. Organ wewnętrzny nie może wprowadzić innych kryteriów niż wskazane przez ustawodawcę.

Po drugie, ustawa o postepowaniu przed TK nie przewiduje wprost dodatkowych albo odmiennych (niż w art. 38) kryteriów adresowanych do Prezesa TK przy wyznaczaniu członków składu (innych niż sprawozdawca i przewodniczący). Gdyby ustawodawca dopuszczał taką możliwość, uregulowałby to zagadnienie wprost, tak jak uczynił to w odniesieniu do sprawozdawcy i przewodniczącego składu, którzy mogą zostać wyznaczeni przez Prezesa TK przy zastosowaniu innych - niezdefiniowanych wprost - kryteriów (art. 38 ust. 2 i art. 37 ust. 2 ustawy o postępowaniu przed TK). Przeciwne rozumowanie podważałoby sens wyodrębnienia art. 38 ust. 2 oraz godziłoby w ratio wprowadzenia - empirycznie weryfikowalnych - kryteriów wyznaczenia tzw. zwykłych członków składu.

Po trzecie, w przypadku kompetencji Prezesa TK można mówić o stabilnej tendencji legislacyjnej. Począwszy od 1997 r. wyznaczenie członków składu orzekającego zawsze było ograniczone kryterium alfabetycznym ${ }^{11}$. W porównaniu z stanem prawnym obowiązujacym od 1997 r. w latach 2015-2016 zmieniono brzmienia ustawowych kryteriów wyznaczenia sędziego do składu orzekajacego TK. Ustawodawca zastapił kryterium przydziału według kolejności spraw kryterium alfabetycznym. Zarazem ustawodawca wprowadził trzy dodatkowe kryteria (rodzaju, ilości i wpływu sprawy). Zmiana ta nie stanowiła jednak nowości, gdyż pod rządami ustawy o TK z 1997 r. kryterium alfabetyczne stosowane było na podstawie przepisów regulaminu TK. W świetle obowiązujących w 2015 r. przepisów Prezes TK wyznaczał skład „zgodnie z alfabetyczną listą sędziów”.

9 Szerzej o zrębowości zob. Zieliński (2017): 108-109.

10 Szerzej o modyfikacji zob. Zieliński (2017): 111-122.

11 Zob. kolejno: art. 26 ust. 3 ustawy o TK z 1997 r.; $\$ 26$ załącznika do uchwały Zgromadzenia Ogólnego Sędziów Trybunału Konstytucyjnego z 3 października 2006 r. w sprawie regulaminu Trybunału Konstytucyjnego, M.P. Nr 72, poz. 720; art. 45 ust. 1 ustawy o TK z 2015 r.; art. 1 pkt 16 ustawy z 22 grudnia 2015 r. o zmianie ustawy o Trybunale Konstytucyjnym, Dz. U. poz. 2217; art. 26 ust. 3 ustawy o TK z 2016 r. 
W świetle obecnie obowiązującej regulacji skład „wyznacza Prezes TK według kolejności alfabetycznej”. Uchwalone w latach 2015-2016 przepisy w istocie usankcjonowały praktykę stosowania ustawy o TK z $1997 \mathrm{r}$.

W konsekwencji za niedopuszczalne uważam wyznaczenie składu orzekającego przy zastosowaniu innych kryteriów niż wskazane w art. 38 ust. 1 ustawy o postępowaniu przed TK. O tym, że nie jest to sytuacja czysto hipotetyczna, świadczy zaś stanowisko sędziów TK ${ }^{12}$ oraz analiza zarządzeń Prezesa TK wydanych w $2017 \mathrm{r}^{13}$

\section{ZMIANA W SKŁADZIE ORZEKAJĄCYM}

Ustawa stanowi o „wyznaczeniu” sędziów TK „do składu orzekającego”, wyznaczeniu „przewodniczącego składu i sędziego sprawozdawca[y]” (art. 38), a także o składach „wyznaczonych do rozpoznania danej sprawy” (art. 37 ust. 1 pkt 1 lit. e. W praktyce prawniczej ${ }^{14}$ rozpowszechnione jest określenie „zmiany w składzie orzekającym”. Jest to zwrot języka prawniczego stosowany na oznaczenie sytuacji, w której mocą zarządzenia Prezesa TK do składu orzekającego wyznaczony zostaje sędzia Trybunału na miejsce innego - wcześniej wyznaczonego - sędziego TK. Zwrot „zmiana składu orzekającego” odnosi się z kolei do sytuacji, w której zarządzeniem Prezesa TK wcześniejszej wyznaczony skład zostaje „zastapiony” innym (np. złożonym z innych sędziów niż wyznaczeni pierwotnie do rozpoznania sprawy albo pełnym składem TK). Nie są to ani sytuacje rzadkie, ani niezwykłe. Sa dopuszczalne ze względów pragmatycznych, z uwagi na brak reguły niezmienności składu oraz brzmienie art. 37 ust. 1 pkt 1 lit. e ustawy o postępowaniu przed TK. Powstaje jednak pytanie o podstawę prawną i granicę kompetencji Prezesa TK nie tyle do „pierwszego" w sprawie wyznaczenia sędziów do składu, ile do zmiany w składzie lub zmiany raz już wyznaczonego składu ${ }^{15}$.

Uważam, że - znajdujące oparcie w brzmieniu ustawy - pojęcie wyznaczenia sędziów obejmuje „pierwsze wyznaczenie sędziów” oraz kolejne modyfikacje (tj. zmianę w składzie i zmianę składu). Tym samym odnosi się do każdej - mającej za przedmiot kształtowanie składu orzekającego - czynności Prezesa TK

${ }_{12}$ Zob. list sędziów TK z 15 listopada 2018 r., <https://archiwumosiatynskiego.pl/wpis-w-debacie/list-pieciorga-sedziow-tk-w-sprawie-istotnych-problemow-wynikajacych-z-dzialalnosci-orzecznictwa-trybunalu-konstytucyjnego-w-2017-roku/> [dostęp: 10.04.2019].

${ }^{13}$ Ziółkowski (2018): 135; Pyziak-Szafnicka (2020): 23 n.

${ }^{14}$ Prezes TK nie jest konsekwentny w stosowanej terminologii. Organ ten wydaje bowiem zarządzenia o wyznaczeniu sędziów do składu (tj. zgodnie z litera ustawy), „o zmianie składu” oraz „zmianie w składzie orzekającym” (np. zarządzenie Prezesa TK 8 lutego 2017 r. o zmianie w składzie orzekającym w sprawie o sygn. SK 3/13, niepublikowane, ale dostępne w elektronicznej bazie Archiwum Osiatyńskiego; mocą tego zarządzenia do składu wyznaczono osoby niebędące sędziami TK, tj. Mariusza Muszyńskiego i Henryka Ciocha).

15 O tym, że nie jest to kwestia hipotetyczna, świadczy praktyka Prezes TK w latach 20172018 r. oraz twierdzenie Muszyńskiego (zdanie odrębne do uzasadnienia postanowienia TK z 22 marca 2018 r., K 9/16, OTK ZU-A 2018, poz. 21). 
dokonywanej zarówno po wpisaniu sprawy do repertorium, jak i na późniejszych etapach rozpoznania sprawy. Niezależnie od tytułu zarządzenia Prezesa TK każdorazowo dokonuje on „wyznaczenia sędziów do składu TK”. Pojęcie składu jest bowiem pojęciem ustawowo zdefiniowanym (np. pełny skład TK). Ściśle więc rzecz ujmując, składów się nie zmienia. W tym ujęciu podstawę działań Prezesa TK zawsze stanowi art. 38 ust. 1. „Zmiana składu” lub „zmiana w składzie orzekającym" może się dokonać wyłącznie przy uwzględnieniu kryteriów: kolejności wpływu, alfabetycznego oraz rodzaju i liczby spraw.

Przyjęcie odmiennego zapatrywania aktualizowałoby pytanie o podstawę prawną czynności Prezesa TK. Kompetencji tej nie można wszakże domniemywać (art. 7 Konstytucji) ${ }^{16}$. W polskim porządku konstytucyjnym nie przyjmuje się zaś koncepcji implied powers. Sam tylko wzgląd na skuteczność lub efektywność organu władzy publicznej nie może przemawiać za przyznaniem organowi kompetencji do działania ${ }^{17}$. Kompetencja do kolejnego w sprawie wyznaczenia sędziów do składu nie może zatem wynikać z ogólnego upoważnienia Prezesa TK do kierowania pracami Trybunału (art. 12 ust. 1 pkt 1), skoro upoważnienie to jest wielokrotnie szczegółowo rozwijane lub modyfikowane w kolejnych przepisach.

Ponadto brak ograniczenia Prezesa TK przy zmianie w składzie lub zmianie składu kryteriami wynikajaccymi z art. 38 ust. 1 podważałby sens gwarancyjny tego przepisu. Prezes TK mógłby najpierw wyznaczyć sędziów zgodnie z ustawowymi kryteriami, a następnie arbitralnie zniweczyć wymagany przez ustawodawcę skutek. Takiego symbolicznego charakteru pierwszej czynności Prezesa TK i arbitralności kolejnych nie sposób pogodzić z konstytucyjnymi wymogami sprawiedliwości proceduralnej, w tym stabilności i przewidywalności procedury postępowania przed TK. Nawet gdyby twierdzić, że art. 45 ust. 1 Konstytucji nie znajduje bezpośredniego zastosowania do postępowań, o których mowa $\mathrm{w}$ art. 188 Konstytucji, sa one objęte wymogami wynikającymi z art. 2 Konstytucji. Przepis ten zaś - zgodnie z utrwaloną koncepcja - wyraża nie tylko zakaz arbitralności, ale i podstawowe wymogi sprawiedliwości proceduralnej. Konieczność spełnienia tych wymogów w postępowaniu przed TK uwidacznia się w szczególności w sprawach inicjowanych pytaniem prawnym, skargą konstytucyjna albo wnioskiem podmiotu o ograniczonej legitymacji. Podyktowana arbitralnymi wyborami Prezesa TK zmiana składu w tych postępowaniach mogłaby in casu prowadzić do naruszenia ich praw podmiotowych zagwarantowanych przez wiążące Polskę umowy międzynarodowe (np. art. 6 EKPC).

\section{WYZNACZENIE SĘDZIEGO SPRAWOZDAWCY}

Wyznaczenie sprawozdawcy uregulowano w obu jednostkach redakcyjnych art. 38 ust. 2 ustawy o postępowaniu przed TK. Pierwsza odnosi się do wyznaczenia sprawozdawcy zgodnie z kryterium alfabetycznym, wpływu, rodzaju

16 Zob. mutatis mutandis wyrok TK z 23 marca 2006 r., K 4/06, OTK ZU 2006, nr 3, poz. 32.

17 Por. m.in. Sokolewicz, Zubik (2016): 251-252. 
i liczby sprawy. Zgodnie z drugą sprawozdawcę można wyznaczyć bez zachowania tych kryteriów w „uzasadnionych przypadkach, zwłaszcza ze względu na przedmiot rozpoznawanej sprawy”. Analiza praktyki Prezesa TK ${ }^{18}$ skłania do pytania: czy art. 38 ust. 2 odnosi się tylko do sytuacji pierwszego w sprawie wyznaczenia sprawozdawcy, czy też do każdej kolejnej zmiany.

Prima facie można by twierdzić, że skoro art. 38 ust. 1 dotyczy zarówno (pierwszego) wyznaczenia składu orzekającego, jak i każdej późniejszej jego zmiany, to konsekwentnie art. 38 ust. 2 (lex specialis) powinien odnosić się zarówno do pierwszego wyznaczenia sprawozdawcy, jak i każdej późniejszej jego zmiany przez Prezesa TK. Interpretacja ta wydaje się również pragmatycznym rozwiązaniem, pozwalającym Prezesowi TK usprawniać przebieg procesu sędziowskiej deliberacji w celu szybszego wypracowania kompromisu i rozstrzygnięcia ${ }^{19}$.

W moim jednak przekonaniu art. 38 ust. 2 ustawy o postępowaniu przed TK odnosi się jedynie do sytuacji pierwszego wyznaczenia sprawozdawcy w sprawie, która została przyjęta do merytorycznego rozpoznania przez TK, a nie do kolejnych zmian sprawozdawcy moca zarządzenia Prezesa TK. Każda ewentualna późniejsza zmiana w zawisłej sprawie winna spełniać kryteria: alfabetyczne, wpływu, rodzaju i liczby sprawy. W szczególności zmiana sprawozdawcy z pominięciem tych kryteriów nie powinna stanowić sposobu rozwiązania impasu spowodowanego brakiem kompromisu sędziów co do kierunku lub uzasadnienia ${ }^{20}$.

Ograniczenie kompetencji i wpływu Prezesa TK w tym kontekście znajduje odzwierciedlenie w tendencji legislacyjnej i generalnym założeniu ustawodawcy dotyczącym podziału kompetencji między Prezesem TK a składem orzekającym, a w szczególności jego przewodniczącym. Wszakże po chwilowym ustawowym wzmocnieniu wewnętrznej pozycji Prezesa TK w ustawie z czerwca 2015 r. ustawodawca finalnie powrócił do wielu rozwiązań znanych ustawie z 1997 r. Co więcej, obowiązujące przepisy ustawowe (zawarte m.in. w rozdziale 7 i 8) uzasadniaja generalne założenie, że po pierwszym wyznaczeniu składu orzekającego przez Prezesa TK dalej on sprawa administracyjnie „kieruje przewodniczy”, a „merytorycznie” - sędzia sprawozdawca. Niezgodne

${ }_{18}$ Np. mocą zarządzeń Prezesa TK z 4 stycznia 2017 r. w sprawach: K 23/16, K 2/15, U 2/16 oraz SK 18/16 (niepubl.) zmieniono wyznaczonego wcześniej sprawozdawcę, powierzając tę funkcję Muszyńskiemu. Prezes TK powołał się przy tym na art. 38 ust. 2 ustawy o postępowaniu przed TK jako podstawę do każdorazowej zmiany sprawozdawcy niezależnie od etapu postępowania.

${ }^{19}$ Modelowa wydaje się sytuacja, w której Prezes TK, pomijając ustawowe kryteria, najpierw - zgodnie z art. 38 ust. 2 ustawy o postępowaniu przed TK - wyznacza na sprawozdawcę sędziego specjalizującego się w odpowiedzialności odszkodowawczej Skarbu Państwa, który w trakcie rozpoznania sprawy nie jest w stanie przekonać pozostałych członków składu do proponowanego kierunku rozstrzygnięcia lub uzasadnienia. Następnie Prezes, również korzystając z tego samego przepisu, wyznacza na sprawozdawcę innego sędziego specjalizującego się również $\mathrm{w}$ tej samej dziedzinie.

${ }^{20} \mathrm{~W}$ takiej sytuacji sprawa powinna zostać przekazana do rozpoznania pełnemu składowi TK. Przyjmuję bowiem, że subiektywno-obiektywne rozumienie ustawowego pojęcia „sprawy o szczególnej zawiłości” (art. 37 ust. 1 pkt 1 lit. e ustawy o postępowaniu przed TK). Z perspektywy deliberatywnego konstytucjonalizmu sprawa staje się szczególnie zawiła, jeżeli wyróżniający się wiedzą prawniczą sędziowie nie są w stanie osiagnąć kompromisu. 
z tym założeniem byłoby przyznanie Prezesowi TK kompetencji do wyznaczania drugiego i kolejnego sprawozdawcy w sprawie na podstawie art. 38 ust. 2 ustawy o postępowaniu przed TK.

Niewątpliwie stanowiąc o „uzasadnionych przypadkach”, ustawodawca pozostawił Prezesowi TK luz interpretacyjny. Zarazem jednak ograniczył go przykładowym wskazaniem takiego przypadku (tj. ,przedmiot[em] rozpoznawanej sprawy"21). Takie sformułowanie skłania mnie zaś do twierdzenia, że $\mathrm{w}$ analizowanym przepisie chodzi jedynie o uzasadnione obiektywne sytuacje istniejacce na etapie wpływu i wpisania sprawy do repertorium. Moim zdaniem nie można zakwalifikować jako „uzasadnionego przypadku” sytuacji, która pojawiła się już w toku rozpoznania sprawy przez wyznaczony skład ${ }^{22}$. Taka sytuacja nie jest bowiem podobna do tej, którą jako przykład wskazał ustawodawca w art. 38 ust. 2.

Analizowany przepis wprowadza wyjątek od - doniosłej z perspektywy zasad sprawiedliwości proceduralnej i transparentności - reguły związania Prezesa TK ustawowymi kryteriami wyznaczania sędziów do składu. Tym samym wyjątek ten należy interpretować zawężająco. Odmienne rozumowanie mogłoby in casu prowadzić do wykreowania po stronie Prezesa TK środków - niedopuszczalnego konstytucyjnie - nadzoru merytorycznego nad sprawozdawca.

\section{KRYTERIA WYZNACZANIA ${ }^{23}$}

Artykuł 38 ust. 1 ustawy o postępowaniu przed TK nie wskazuje wprost preferencji ustawodawcy odnośnie do doniosłości lub kolejności stosowania kryteriów: alfabetycznego, rodzaju, liczby i kolejności spraw. Prima facie wydawać by się mogło, że to kryterium alfabetyczne stanowi podstawę, a kryterium kolejności wpływu spraw pełni funkcję modyfikującą (tak jak kryterium liczby i rodzaju sprawy). W praktyce nie sposób jednak oddzielić zastosowania kryterium alfabetycznego od kryterium kolejności wpływu ${ }^{24}$.

Wyrażam pogląd, że analizowany przepis przewiduje dwuetapową procedurę wyznaczania członków składu orzekającego TK. Ustawodawca wprowadził dwojakiego rodzaju kryteria: I stopnia (tj. alfabetyczne i kolejności spraw) oraz II stopnia („uwzględniajacc przy tym rodzaje, liczbę [...] spraw”). Na pierwszym etapie stosowania mechanizmu ustawowego Prezes TK powinien

${ }^{21}$ Ratio tego rozwiązania wyraża się w uwzględnieniu przez ustawodawcę faktu, że jeden lub kilku sędziów TK może posiadać szczególną wiedzę albo doświadczenie, które mogą w warunkach konkretnej sprawy okazać się przydatne do jej rozpoznania, zwłaszcza jeżeli jest ona szczególnie zawiła z uwagi na przedmiot kontroli. Tego rodzaju wiedza lub doświadczenie sędziów TK znane są jednak Prezesowi TK z urzędu i nie zmieniają się w czasie.

${ }_{22}$ Np. Prezes TK nie podziela kierunku rozstrzygnięcia zaproponowanego przez sprawozdawcę albo skład pięciu sędziów TK nie może dojść do porozumienia ze sprawozdawca, a zarazem nie chce przekazać sprawy do rozpoznania pełnemu składowi.

23 Ziółkowski (2018): 114-117.

24 Nieprzypadkowo ustawa o TK z 1997 r. traktowała kryterium wpływu jako punkt wyjścia poprzedzający zastosowanie kryterium alfabetycznego, o którym stanowił regulamin TK z 2006. 
kierować się kryterium kolejności wpływu oraz kryterium alfabetycznym. Dopiero na drugim etapie uzyskany w ten sposób wynik powinien zmodyfikować, stosujac kryterium rodzaju i liczby spraw. O ile kryterium alfabetyczne i liczby spraw nie powinno budzić wątpliwości interpretacyjnych, o tyle kryteria II stopnia nie sa tak jednoznaczne.

Pierwsze z nich, czyli kryterium „rodzaju spraw”, należy - w moim przekonaniu - rozumieć w świetle konstytucyjnie określonej kognicji TK (art. 188, art. 131, art. 189 Konstytucji). Tylko takie rozumienie ustawowego wyrażenia „rodzaj sprawy” nie narusza zakazu wykładni synonimicznej ${ }^{25}$, nie prowadzi do wewnętrznej niespójności na gruncie przepisów ustawy ${ }^{26}$, nie narusza kompetencji Prezesa TK z art. 37 ust. 1 pkt 1 lit. e ustawy o postępowaniu przed $\mathrm{TK}^{27}$ ani nie podważa istoty mandatu sędziego $\mathrm{TK}^{28}$. Powiazanie ustawowego wyrażenia „rodzaj sprawy” z kognicja TK, a nie przedmiotem lub wzorcem kontroli, wynikające z zastosowania rozumowania a contrario do art. 38 ust. 2 ustawy o postępowaniu przed TK, pozwala zobiektywizować analizowane kryterium i uniemożliwia obchodzenie przez Prezesa TK kryterium alfabetycznego. Stoi bowiem na przeszkodzie włączaniu - formułowanych a casu ad casum przez Prezesa TK - ocen dotyczących poszczególnych sędziów Trybunału w procedurę wyznaczania składów orzekających. Odpowiada więc ratio legis instytucji wyznaczania składu orzekającego oraz postulatowi stabilności wyznaczonych już składów orzekających. Z uwagi na ustawowy nakaz rozpoznania niektórych rodzajów spraw w pełnym składzie TK (art. 37 ust. 1 pkt 1 ustawy o postępowaniu przed TK), a więc w sytuacji, w której ustawa wprost i bezwzględnie określa skład orzekający (rozumiany jako wszyscy sędziowie TK zdolni do orzekania ${ }^{29}$ ), kryterium „rodzaju sprawy” znajduje zastosowanie jedynie w sprawach rozpoznawanych w składach pięcio- i trzyosobowych. Innymi słowy, odstępstwo od rezultatu zastosowania kryteriów kolejności wpływu i alfabetycznego przy wyznaczaniu składu orzekającego z powołaniem się na kryterium „rodzaju sprawy” ma zapobiegać sytuacji, w której sprawy tego samego rodzaju (np. dotyczace konstytucyjności ustaw, rozporządzeń albo wyłączenia sędziego) byłyby rozpoznawane przez tych samych sędziów TK.

${ }^{25}$ Zważywszy, że ustawodawca wprowadził kryterium „przedmiotu rozpoznawanej sprawy” w art. 38 ust. 2 ustawy o postępowaniu przed TK, nie ma podstaw, by w ten sam sposób rozumieć kryterium „rodzaju sprawy” z art. 38 ust. 1 tej ustawy. Zob. szerzej Ziółkowski (2018): 114-117.

${ }^{26}$ Artykuł 38 ust. 2 ustawy o postępowaniu przed TK należałoby wówczas uznać albo za zbędny, albo za zakresowo zbieżny z art. 38 ust. 1 tejże ustawy. Zob. szerzej Ziółkowski (2018): $114-117$.

${ }^{27}$ Do takiej sytuacji doszłoby, gdyby kryterium „rodzaju sprawy” rozumieć jako odwołujace się do oceny stopnia jej skomplikowania przez Prezesa TK. Ocena taka - choćby wstępna - nie jest możliwa na etapie wyznaczania składu orzekającego bez merytorycznego wglądu w treść wniosku, pytania prawnego albo skargi konstytucyjnej. Zob. szerzej Ziółkowski (2018): 114-117.

${ }^{28}$ Do takiej sytuacji doszłoby, gdyby kryterium „rodzaju sprawy” rozumieć z perspektywy wzorca kontroli. Wówczas Prezes TK, wyznaczając składy orzekające, musiałby przyjać założenie o swoistej „specjalizacji” sędziów Trybunału w zakresie wzorców konstytucyjnych. Zob. szerzej Ziółkowski (2018): 114-117.

${ }^{29}$ Takie rozumienie przyją TK w sprawach K 47/15 i K 44/16. Pogląd ten pozostaje aktualny również w obecnym stanie prawnym. Jest on bowiem oparty na analizie przepisów konstytucyjnych. 
Drugie z kryteriów II stopnia (tj. modyfikujących zastosowanie kryteriów kolejności wpływu i alfabetycznego), czyli kryterium „liczby spraw”, należy rozumieć w świetle równego konstytucyjnie statusu sędziów TK. Zważywszy na brak odrębnej konstytucyjnej regulacji statusu Prezesa i wiceprezesa TK oraz odrzucenie przez prawodawcę konstytucyjnego koncepcji senatów sądu konstytucyjnego lub specjalizacji sędziów TK, należy przyjąć, że wszyscy sędziowie Trybunału w jednakowym stopniu powinni uczestniczyć w rozpoznawaniu spraw przez TK. Z uwagi na zróżnicowanie przedmiotów i wzorców kontroli, odmienne zakresy zaskarżenia oraz stopień zawiłości spraw, nieunikniona jest sytuacja, gdy poszczególni sędziowie TK będą mieli w swoich referatach różną liczbę spraw, z których każda będzie rozpoznawana w innym tempie. Zniwelowaniu tych różnic i zapewnieniu równego obciążenia ma służyć właśnie kryterium „liczby spraw”. Innymi słowy, odstępstwo od wyniku zastosowania kryteriów kolejności wpływu i alfabetycznego przy wyznaczaniu składu orzekającego z powołaniem się na wspomniane kryterium liczby spraw służy zachowaniu równego obciążenia sędziów TK. Tym samym nie chodzi tu o liczbę spraw danego rodzaju przypadającą na poszczególnego sędziego TK, ale o ogólną liczbę spraw w referacie.

\section{OKOLICZNOŚĆ}

Od problematyki związania Prezesa TK kryteriami wynikającymi z art. 38 ust. 1 ustawy o postępowaniu przed TK należy odróżnić okoliczności, w których zmiana składu lub w składzie jest w ogóle dopuszczalna. Kryteria alfabetyczne, wpływu, rodzaju i liczby spraw odnoszą się bowiem do tego, jak skład wyznaczyć lub zmienić, a nie kiedy tego dokonać. Ustawa nie rozstrzyga tej kwestii wprost ${ }^{30}$. Nie wydaje się jednak kontrowersyjne, że treściowe ograniczenia normy kompetencyjnej Prezesa TK moga być rekonstruowane z różnych przepisów ustawy, zwłaszcza jeżeli przemawia za tym konieczność realizacji konstytucyjnej zasady niezawisłości sędziów TK, zasady sprawiedliwości proceduralnej w postępowaniu przed Trybunałem oraz ochrona konstytucyjnych wartości, jakimi są sprawność i rzetelność działania TK. Należy przy tym uwzględnić utrwalone sposoby odczytania swej kompetencji przez kolejnych prezesów TK.

W moim przekonaniu pozostawienie Prezesowi TK swobody decydowania o okolicznościach, w których może on dokonać zmiany w składzie orzekającym, nie sposób pogodzić z konstytucyjnym nakazem zagwarantowania niezawisłości wewnętrznej sędziego wyznaczonego do rozpoznania sprawy

${ }^{30}$ O tym, że pytanie o ustawowe okoliczności uzasadniające wydanie przez Prezesa TK zarządzenia o zmianie składu orzekającego TK nie jest zagadnieniem wyłącznie hipotetycznym, świadczą m.in. zarządzenia Prezesa TK z 11 stycznia 2017 r. w sprawach: K 26/15, P 43/13, SK 3/14, SK 19/15 oraz SK 32/15 (niepubl.), w których treści wskazano, że zmiana składu orzekającego została dokonana ,ze względów organizacyjnych”, a więc z uwagi na wysoce ocenną okoliczność nieznaną ustawie. 
zawisłej przed Trybunałem ${ }^{31}$. Pojęcie to nie ogranicza się tylko do kwestii stosunku sędziego do osobistych przekonań, ale obejmuje również niezawisłość wewnętrzną w ujęciu instytucjonalnym ${ }^{32}$. Niezawisłość polega wszakże na „stworzeniu sędziemu takiej sytuacji, by w wykonywaniu swoich czynności mógł on podejmować bezstronne decyzje w sposób zgodny z własnym sumieniem i zabezpieczony przed możliwością bezpośrednich lub pośrednich nacisków zewnętrznych” ${ }^{33}$. Tak rozumiana „niezawiłość znacznie trudniej toleruje jakiekolwiek ograniczenia" ${ }^{34}$. Kluczowe jest w tym kontekście rozróżnienie, które przyją TK w wyroku K 39/16 na: niezawisłość obiektywną (tj. od innych podmiotów prawa) oraz subiektywną (czyli zdolność do abstrahowania sędziego od pozaprawnych zasad i wartości). Konstytucyjny wymóg niezawisłości sędziego TK oznacza zatem również konieczność stworzenia mu takich warunków sprawowania urzędu, które będą wolne od - nieprzewidzianego wprost w przepisach konstytucyjnych lub ustawowych - wpływu organu wewnętrznego Trybunału (tj. jego Prezesa, wiceprezesa lub Zgromadzenia Ogólnego Sędziów TK) ${ }^{35}$. Za wpływ tego rodzaju należy uznać możliwość wyznaczenia przez Prezesa TK - w oderwaniu od jakichkolwiek kryteriów ustawowych - sędziego TK w miejsce innego sędziego uprzednio już wyznaczonego do składu orzekającego.

Pozostawienie Prezesowi TK swobody do decydowania o okolicznościach, w których może on dokonać zmiany w składzie orzekającym, byłoby równoznaczne z przyznaniem temu organowi środków wpływu na pracę merytoryczną (a niekiedy i na kierunek orzeczenia) składu orzekającego, którego Prezes TK nie jest członkiem. Mógłby on - w zależności od sytuacji faktycznej - zmieniać skład w taki sposób, aby jego członkami byli wyłącznie sędziowie TK podzielający kierunek rozstrzygnięcia preferowany przez Prezesa TK. Sytuacja taka nie odpowiada zaś konstytucyjnej funkcji Prezesa TK, zasadzie niezawisłości sędziów TK oraz regule kolegialności przy rozstrzyganiu spraw. Należy bowiem przypomnieć, że przepisy konstytucyjne, które konsekwentnie stanowią o organie władzy publicznej, a nie jego piastunie, a przy tym nie różnicują statusu sędziego TK i sędziego TK powołanego na stanowisko Prezesa TK, wymagaja zachowania zasady primus inter pares. Takie też postrzeganie Prezesa TK uzasadnia wieloletnia tendencja legislacyjna oraz praktyka stosowania przepisów ustawowych. Nie ma tym samym podstaw, aby w drodze interpretacji ustawy przyznać Prezesowi TK kompetencje quasi-nadzorcze nad merytoryczną pracą sędziów wyznaczonych już raz do jego składu orzekającego.

Ponadto nieograniczona treściowo kompetencja Prezesa TK do zmiany składu orzekającego nie służy realizacji konstytucyjnej zasady rzetelności i sprawności działania instytucji publicznych (preambuła do Konstytucji). W warunkach konkretnej sprawy może pojawić się bowiem wątpliwość do-

\footnotetext{
${ }^{31}$ Wyrok TK z 9 marca 2016 r., K 47/15: cz. III, pkt 6.1.7.

${ }^{32}$ Wyrok TK z 11 sierpnia 2016 r., K 39/16: pkt III.7.2.

${ }^{33}$ Garlicki (2005): 3; Sokolewicz (2006): 175-178; Brzozowski (2016): 42-50.

${ }^{34}$ Garlicki (2005): 6.

${ }^{35}$ Wyrok TK z 11 sierpnia 2016 r., K 39/16: pkt III.7.2.
} 
tycząca spełniania zarówno wymogu sprawności ${ }^{36}$, jak i rzetelności ${ }^{37}$. Każda zmiana w składzie orzekającym, a w szczególności zmiana sprawozdawcy, winna skutkować wyznaczeniem kolejnych narad w celu dostatecznego wyjaśnienia sprawy. Z perspektywy wymogu rzetelności niedopuszczalne jest wyrokowanie w sytuacji, w której w następstwie zmiany składu orzekającego przez Prezesa TK członkowie składu nie zapoznali się wnikliwie ze zgromadzonym materiałem procesowym przed rozprawą. Wątpliwość taka może pojawić się zwłaszcza wtedy, gdy - tuż przed wyrokowaniem - moca zarządzenia Prezesa TK do składu orzekającego zostaje wyznaczony sędzia TK, który nie brał dotąd udziału w naradach (albo nawet i w samej rozprawie).

W świetle dotychczasowych ustaleń uważam, że na podstawie obowiąującej regulacji ustawowej można bronić poglądu o numerus clausus okoliczności zmiany w składzie lub zmiany składu orzekającego TK. Zarządzenie Prezesa TK może zostać wydane jedynie w ściśle i ustawowo określonych okolicznościach, a są to: a) upływ kadencji sędziego TK; b) wygaśnięcie mandatu sędziego (art. 18 ust. 1); c) wyłączenie sędziego TK (art. 39-41); d) choroba, ułomność lub utrata sił, która skutkuje okresową (a nie trwała) niezdolnością do pełnienia obowiązków sędziego TK (art. 32); e) odmowa przez sędziego TK udziału w wyrokowaniu z naruszeniem konstytucyjnego obowiązku orzekania (casus powstały w sprawie K 44/16 $6^{38}$ ). Tym samym podstawa zmiany składu orzekającego nie mogą być w szczególności: a) brak aprobaty Prezesa TK dla kierunku rozstrzygnięcia zaproponowanego przez sprawozdawcę, b) brak aprobaty członków składu orzekającego dla kierunku rozstrzygnięcia zaproponowanego przez sprawozdawcę, c) urlop sędziego TK; d) zdarzenie losowe stanowiące jednorazową przeszkodę w udziale sędziego TK w wyrokowaniu; e) okoliczności lub względy organizacyjne.

\section{NASTĘPSTWA}

Naruszenie wymogów dotyczących czynności konwencjonalnej może pociągać za sobą różne następstwa, w tym nieważność czynności lub jej wytworu. Naruszenie to może wywoływać również innego rodzaju skutek (np. wzruszalność), a ponadto generować odpowiedzialność odszkodowawczą (np. podmiotu szkodzącego albo innego podmiotu za szkodę odpowiedzialnego).

Z teoretycznej perspektywy uwzględniającej rozróżnienie ${ }^{39}$ reguł formalizujących i konwencjonalizujących ${ }^{40}$ czynności konwencjonalnej większość

36 Szerzej o „sprawności” zob. wyrok TK z 11 sierpnia 2016 r., K 39/16: pkt III.6.1.

37 Szerzej o „rzetelności” zob. wyrok TK z 11 sierpnia 2016 r., K 39/16: pkt III.6.1.

38 Po raz pierwszy w historii orzecznictwa konstytucyjnego w części merytorycznej uzasadnienia wyroku TK zawarto informację o podjętych przez jego sędziów działaniach, które miały bezpośrednio uniemożliwić mu zrealizowanie jego konstytucyjnej kompetencji i wydanie wyroku. Z. Jędrzejewski, J. Przyłębska i P. Pszczółkowski w dniu rozprawy w sprawie K 44/16 odmówili wykonania swoich konstytucyjnych obowiązków - szerzej o precedensie zob. Ziółkowski (2019): 20-22.

39 Szerzej zob. Czepita (2006): 9-28.

${ }^{40}$ Czepita (2014): 6. 
omówionych powyżej wymogów, dotyczących wyznaczenia przez Prezesa TK sędziów do składu orzekającego, ma charakter formalizujacy ${ }^{41}$. Ich naruszenie nie powinno zatem oznaczać niedojścia czynności konwencjonalnej Prezesa TK do skutku. Czynność taka byłaby wówczas ważna, choć niewątpliwie wadliwa. Przykładem takiej czynności jest, w moim przekonaniu, wydanie przez Prezesa TK zarządzenia o wyznaczeniu sędziów TK do składu z pominięciem części albo wszystkich kryteriów z art. 38 ust. 1 ustawy o postępowaniu przed TK. Innym przykładem jest wyznaczenie drugiego sędziego sprawozdawcy w konkretnej sprawie na podstawie art. 38 ust. 2 ustawy o postępowaniu przed TK. Natomiast jako naruszenie reguły konwencjonalizującej jawi się wydanie przez Prezesa TK zarządzenia o wyznaczeniu do składu orzekającego osoby, która nie jest sędzia TK (np. osoby wybranej przez Sejm VIII kadencji na stanowisko sędziego TK legalnie obsadzone przez Sejm VII kadencji). Podobnie, moim zdaniem, należy ocenić sytuację, w której członków składu orzekającego wyznacza osoba niebędacca Prezesem TK (np. sędzia wybrany i powołaną na stanowisko w nieważnej procedurze). Ilustracją tych problemów jest wyrokowanie przez TK z udziałem m.in. Julii Przyłębskiej i Mariusza Muszyńskiego.

Z konstytucyjnoprawnej perspektywy rozważania o ewentualnej nieważności lub innego rodzaju wadliwości analizowanej czynności konwencjonalnej Prezesa TK powinny uwzględniać - doniosłe nie tylko w kontekście kryzysu konstytucyjnego - stanowisko sformułowane w sprawie U 8/15, w której TK rozdzielił dwie perspektywy dyskusji (publicznoprawną i teoretycznoprawna ${ }^{42}$ ) o wadach i skutkach czynności konwencjonalnych konstytucyjnych organów władzy publicznej. Zarazem w orzeczeniu tym TK, po raz pierwszy stanowczo i wprost, wprowadził do orzecznictwa konstytucyjnego kategorię nieważności w ujęciu teoretycznoprawnym i wskazał na jej doniosłość dla refleksji o prawie konstytucyjnym ${ }^{43}$.

Punktem wyjścia jest zatem twierdzenie, że kwalifikacja jakiejśs czynności konwencjonalnej jako wadliwej z perspektywy teoretycznoprawnej nie zawsze pociaga za sobą analogiczną ocenę na płaszczyźnie prawa publicznego (np. unieważnialność) ${ }^{44}$. Dobrze widać to w obszarze prawa konstytucyjnego, w którym często brak przepisów przesądzających wprost zarówno o charakterze wymogów odnoszących do danej czynności, jak i skutkach jej naruszenia. Tradycyjnie zresztą wiele z wymogów czynności konwencjonalnych dokonywanych na podstawie przepisów konstytucyjnych ma charakter formalizujący ${ }^{45}$, czego najlepszym przykładem wydają się wymogi odnoszące się do czynności

41 Jako formalizujące postrzega się bowiem - wskazane przez normy prawne - wymogi „niemające wpływu na ważność czynności konwencjonalnej, lecz zakazujące dokonywania takiej czynności przez pewne osoby, w danym czasie lub okolicznościach, czy też w określony sposób, względnie upoważniające do jej wzruszenia w ustalonych przypadkach” - Hermann (2013): 253. Zob. również Wronkowska, Hermann (2015): pkt 3.1.

42 Postanowienie TK z 7 stycznia 2016 r., U 8/15, OTK ZU-A 2016, poz. 1.

43 Por. z częściowo krytyczną oceną postanowienia U 8/15 - Radziewicz (2016): 45.

44 Por. na przykładzie TK orzekającego z udziałem osób niebędących sędziami TK - Radziewicz (2017): $53 \mathrm{n}$.

${ }^{45}$ Myśl ta zrodziła się w dyskusji z Mikołajem Hermannem, za co mu dziękuję. 
prawodawczej i konsekwencje naruszenia ${ }^{46}$ (a raczej ich brak w praktyce ${ }^{47}$ ). Ponadto, o ile kwalifikacja jakiejśs czynności konwencjonalnej jako wadliwej z perspektywy teoretycznoprawnej nie wymaga formalnego potwierdzenia, o tyle na gruncie prawa publicznego konieczne jest albo zrekonstruowanie normy określającej skutek naruszenia wymogów, albo wskazanie „urzędowej” - by użyć słów TK - procedury, w której dojdzie do stwierdzenia wadliwości albo unieważnienia.

Ani brak jednoznacznych przepisów prawa konstytucyjnego, określających skutki naruszenia reguł dokonania czynności konstytucyjnego organu władzy publicznej, ani brak jednoznacznie wskazanej w przepisach procedury, w której mogłoby dojść do stwierdzenia takiego naruszenia i określenia jego skutków, nie przekreślają współcześnie możliwości rozstrzygnięcia o konstytucyjnoprawnych następstwach teoretycznie pojmowanej wadliwości czynności konwencjonalnej ${ }^{48}$. W takiej sytuacji jednak konieczne jest wykazanie - na podstawie utrwalonego stanowiska orzecznictwa i nauki prawa ${ }^{49}$, w ramach wyznaczony przez porządek prawny i kulturę prawną - ugruntowanych i konstytucyjnych reguł postępowania ${ }^{50}$ wobec naruszeń dokonanych przez konstytucyjne organy władzy publicznej.

W obu wskazanych sytuacjach należy jednak zachować najwyższą staranność i precyzję $e^{51}$. Mnogość wymogów, odnoszących się zarówno do samej czynności konwencjonalnej (np. wyznaczenia składu orzekającego), jak i jej wytworu (zarządzenie Prezesa TK), ich doniosłość, a ponadto złożoność poszczególnych czynności konwencjonalnych (np. wyrokowanie), determinuja mnogość rozwiązań odnoszących się i dla samej czynności, i jej wytworu.

W tym zaś kontekście należy zauważyć, że ani przepisy konstytucyjne, ani przepisy regulujace postępowanie przed TK nie określają konsekwencji naruszenia wymogów czynności konwencjonalnych Prezesa TK oraz samego TK w związku z rozpoznawana sprawa. Przepisy te nie pozostawiaja nawet sędziom wyznaczonym do składu żadnych środków prawnych, które mogłyby posłużyć kwestionowaniu lub przeciwdziałaniu czynnościom Prezesa TK (np. zarządzeniom wydawanym $\mathrm{z}$ naruszeniem lub w celu obejścia art. 38 ust. 2 ustawy o postępowaniu przed TK) ${ }^{52}$. To utrwalona tendencja legislacyjna od

\footnotetext{
46 Szerzej zob. Ziółkowski (2015): 289 n. oraz cyt. orzecznictwo oraz literatura.

${ }^{47} \mathrm{~W}$ teorii prawa wielokrotnie zwracano uwagę, że konstytucjonaliści i TK zaniechali budowy teorii wad czynności prawodawczej albo traktując wszelkie naruszenia jednakowo, albo odwołując się do - wątpliwej teoretycznie i dogmatycznie - konstrukcji kumulacji naruszeń zob. m.in. Czepita (2014): 15; Wronkowska (2018): 17 n. W efekcie problematyka wad czynności prawodawczych staje się coraz bardziej iluzoryczna, czego najlepszym przykładem jest, w moim przekonaniu, stanowisko TK w sprawie skutków wyroków dot. legalności ustawy lub naruszenia wymogu trzech czytań- zob. Ziółkowski (2015).

48 Szerzej zob. Wronkowska, Hermann (2015): pkt 3.1.

49 Szerzej o doniosłości orzecznictwa i doktryny dla prawa konstytucyjnego zob. Wronkowska (2018): 17 i n.

50 Zob. też pogląd Radziewicza (2017): 8.

51 Zob. przykłady problemów podawane przez Hermann (2013): 249 n.

${ }^{52}$ Sędziowie TK kwestionujący legalność zmiany w składzie lub składu TK mogą jedynie składać zdania odrębne, co też czynili w związku z postępującą skalą naruszeń przepisów ustawo-
} 
1997 r., która - w moim przekonaniu - znajduje uzasadnienie: w jednoinstancyjnym charakterze postępowania merytorycznego przed TK, abstrakcyjnym charakterze kontroli oraz koncepcji ostateczności ${ }^{53}$ (rozumianej zarówno jako prawomocność formalna, jak i materialna ${ }^{54}$ ) wyroku TK, a także i braku możliwości wznawiania ${ }^{55}$ lub jakiegokolwiek innego sposobu wzruszenia postępowania $^{56}$ (niezależnie od jego wady - „nieodwracalność wad proceduralnych wyroków Trybunału"57). Czynnościom konwencjonalnym Prezesa TK naruszającym art. 38 ustawy o postępowaniu przed TK, choćby budziły teoretyczny i aksjologiczny sprzeciw, w takiej sytuacji przysługuje „domniemanie ważności” ${ }^{58}$, trudne na płaszczyźnie konstytucyjnoprawnej do wzruszenia wobec braku organu konstytucyjnego i procedury stworzonej ku temu.

Ponadto ewentualna kwalifikacja wad czynności konwencjonalnej Prezesa TK jako doniosłych i naruszających regułę konwencjonalizującą nie przesądza o kwalifikacji konstytucyjnoprawnej wyroku wydanego w sprawie, w której wady te wystapiły. Analizowane czynności Prezesa TK (choćby same były wadliwe i aksjologicznie nieakceptowalne) stanowią element łańcucha kolejnych czynności kompetencyjnych, których należy dokonać, aby TK mógł zrealizować swoją konstytucyjna kompetencję do hierarchicznej kontroli norm. Przykładowo, między innymi z uwagi na utrwaloną interpretację art. 190 Konstytucji dyskusyjne (na obecnym etapie rozwoju polskiego konstytucjonalizmu) może być wnioskowanie o nieważności wyroku TK wyłącznie na podstawie doniosłej wady zarządzenia Prezesa TK, jaka jest wydanie go bez podstawy prawnej (np. wyznaczenie i zmiana składu orzekającego z uwagi na „względy organizacyjne" $\left.{ }^{59}\right)$.

Polski konstytucjonalizm w okresie poprzedzającym kryzys konstytucyjny 2015-2019 nie wypracował utrwalonych reguł postępowania wobec wad czynności Prezesa TK lub samego TK. Nie sposób ich odtworzyć z poglądów utrwalonych $\mathrm{w}$ orzecznictwie lub nauce prawa minionego okresu ${ }^{60}$. Zarazem kryzys ten dał impuls do kształtowania się nowych reguł, które - pod warunkiem ich utrwalenia w systemie i kulturze prawnej - moga w przyszłości posłużyć ocenie działalności obu organów władzy publicznej. Kluczowe w tym kontekście będą w szczególności działania parlamentu kolejnej kadencji, sta-

wych przez Prezesa TK w latach 2017-2019 (np. zdanie odrębne STK S. Wronkowskiej do wyroku TK z 16 marca 2017 r., Kp 1/17, OTK ZU 2017, poz. 28; zdanie odrębne STK P. Tulei do postanowienia TK z 11 października 2017 r., K 14/16, OTK 2017, poz. 69).

${ }^{53}$ Szerzej o pojęciu ostateczności i mocy powszechnie obowiązującej orzeczenia TK zob. Florczak-Wator (2006): 50-66 i cyt. lit.

${ }^{54}$ Garlicki (1997): 83; Czeszejko-Sochacki, Garlicki, Trzciński (1999): 211; Czeszejko-Sochacki (2003): 339.

${ }^{55}$ Zob. postanowienie TK z 17 lipca 2003 r., K 13/02, OTK-A 2003, nr 6, poz. 72.

${ }^{56}$ Szerzej zob. Ziółkowski (2016).

${ }^{57}$ Zob. wyrok TK w sprawie K 47/15: pkt III.1.4.

${ }^{58}$ Radziewicz (2016): 60.

${ }^{59}$ Szerzej o przykładach takich praktyk zob. Ziółkowski (2018): 134-135.

${ }^{60}$ Wydaje się, że nie było ku temu potrzeby, gdyż dopiero skala i głębokość naruszeń prawa konstytucyjnego dokonanych w latach 2015-2019 zdefiniowała nowe problemy polskiego prawa konstytucyjnego, które wymagały reakcji orzecznictwa i doktryny. 
nowisko orzecznictwa oraz rezultaty postępowania przed Europejskim Trybunałem Praw Człowieka w sprawach skarg na naruszenie prawa do rzetelnego procesu w związku z wadliwą obsadą TK i wadliwym wyznaczeniem składów orzekajacych przez TK ${ }^{61}$. Szczególnie pomocne w tym zakresie może okazać się zastosowanie testu „zewnętrznych oznak niezależności”"62 sędziego lub sądu (test of appearance of independence ${ }^{63}$ do oceny postępowania zarówno Prezesa TK, jak i samego TK.

Wskazane powyżej trudności mogą zostać przezwyciężone w przyszłości przez orzecznictwo, doktrynę oraz samego prawodawcę. Nie oznacza to jednak bezbronności systemu prawa w jego aktualnej treści, a zarazem zupełnej bezbronności adresatów norm prawnych wobec wadliwych zarządzeń Prezesa TK o wyznaczeniu sędziów do składu orzekającego. Na poziomie krajowym naruszenie wymogów dotyczących wyznaczenia składów TK może in casu skutkować odpowiedzialnością odszkodowawczą (art. 77 ust. 1 Konstytucji). $\mathrm{Z}$ perspektywy konstytucyjnej kluczowe znaczenie ma stanowisko wyrażone przez TK w sprawie SK 18/0064, rozwinięte i niezakwestionowane następnie $\mathrm{w}$ kolejnych orzeczeniach ${ }^{65}$. Utrwalona w nich interpretacja pozwala objać odpowiedzialnością odszkodowawczą również akty TK oraz Prezesa TK. Co najmniej w sprawach inicjowanych skarga konstytucyjną naruszenie przepisów ustawowych przez Prezesa TK (skutkujące rozpoznaniem sprawy przez osoby niebędące sędziami TK) odpowiada definicji działania niezgodnego z prawem, o którym mowa w art. 77 ust. 1 Konstytucji ${ }^{66}$. Przeszkodą w uwzględnieniu roszczenia w konkretnych sprawach może być - cywilistyczne - pojęcie związku przyczynowego oraz szkody, rozumianej nie tyle jako samo naruszenie praw konstytucyjnych, ile skutek ich naruszenia ${ }^{67}$. Nie sa to jednak przeszkody bezwzględne, ich istnienie zależy bowiem od interpretacji art. 77 ust. 1 oraz art. 190 Konstytucji ${ }^{68}$.

\section{Michat Ziótkowski}

Akademia Leona Koźmińskiego w Warszawie

oraz Europejski Instytut Uniwersytecki we Florencji, Wtochy

mziolkowski@kozminski.edu.pl

https://orcid.org/0000-0001-7019-7193

${ }^{61}$ Zob. np. komunikat ETPC z 2 września 2019 r., Xero Flor w Polsce sp. z o.o. v. Polska, skarga nr 4907/18.

${ }^{62}$ Szerzej o praktycznym zastosowaniu testu zob. Krajewski (2018): 801 n.; Krajewski, Ziółkowski (2020): 1107-1138.

${ }^{63}$ Warto odnotować, że stosowany przez ETPC test został niedawno zaadaptowany przez Rzecznik Generalną TSUE E. Sharpstone do oceny wad czynności konwencjonalnej wyznaczenia członków Sądu do spraw Służby Publicznej Unii Europejskiej (opinia z 12 września 2019 r., C-542/18 RX-II oraz C-543/18 RX-II).

${ }^{64}$ Wyrok TK z 4 grudnia 2001 r., SK 18/00, OTK ZU 2001, nr 8, poz. 256.

${ }^{65}$ Zob. np. wyrok TK z 8 grudnia 2009 r., SK 34/08, OTK ZU-A 2009, nr 11, poz. 165.

${ }^{66}$ Ziółkowski (2017): 205.

${ }^{67} \mathrm{~Np}$. Wojtyczek (2018): $4 \mathrm{n}$.

${ }^{68}$ Ziółkowski (2017): 206-2010. 
Brzozowski, W. (2016). Niezależność konstytucyjnego organu państwa i jej ochrona. Warszawa.

Czepita, S. (2006). Formalizacja a konwencjonalizacja działań w prawie, [w:] S. Czepita (red.), Konwencjonalne i formalne aspekty prawa. Szczecin: 9-28.

Czepita, S. (2014). Czynności konwencjonalne i formalne w prawie a proces prawotwórczy i rola Trybunału Konstytucyjnego. Państwo i Prawo 69(12): 3-19.

Czeszejko-Sochacki, Z. (2003). Sądownictwo konstytucyjne w Polsce na tle porównawczym. Warszawa.

Czeszejko-Sochacki, Z., Garlicki, L., Trzciński, J. (1999). Komentarz do ustawy o Trybunale Konstytucyjnym z dnia 1 sierpnia 1997 r. (Dz.U. nr 102, 643). Warszawa.

Florczak-Wątor, M. (2006). Orzeczenia Trybunału Konstytucyjnego i ich skutki prawne. Poznań.

Garlicki, L. (1997). Uwagi o charakterze prawnym orzeczeń Trybunału Konstytucyjnego, [w:] J. Trzciński, B. Banaszak (red.), Studia nad prawem konstytucyjnym. Acta Universitatis Wratislaviensis. Prawo 257: 82-91.

Garlicki, L. (2005). Uwagi do art. 178, [w:] L. Garlicki (red.), Konstytucja Rzeczypospolitej Polskiej. Komentarz. Tom 4. Warszawa: 3-6.

Hermann, M. (2013). Stwierdzenie niekonstytucyjności jako czynność konwencjonalna unieważnienia aktu normatywnego, [w:] M. Bernatt, J. Królikowski, M. Ziółkowski (red.), Skutki wyroków Trybunału Konstytucyjnego w sferze stosowania prawa. Warszawa: 249-279.

Krajewski, M. (2018). Who is Afraid of the European Council? The Court of Justice's Cautious Approach to the Independence of Domestic Judges ECJ 25 July 2018, Case C-216/18 PPU, The Minister for Justice and Equality v LM, European Constitutional Law Review 14(4): 792-813.

Krajewski, M., Ziółkowski, M. (2020). EU judicial independence decentralized: A.K. Common Market Law Review 57(4): 1107-1138.

Pyziak-Szafnicka, M. (2020). Trybunał Konstytucyjny à rebours. Państwo i Prawo 75(5): 23-46.

Radziewicz, P. (2016). Kontrola konstytucyjności uchwał Sejmu (uwagi na marginesie postanowienia TK w sprawie U 8/15). Państwo i Prawo 71(7): 45-65.

Radziewicz, P. (2017). On legal consequences of judgements of the Polish Constitutional Tribunal passed by an irregular panel. Review of Comparative Law 31: 45-64.

Radziewicz, P., Tuleja, P. (red.) (2017). Konstytucyjny spór o granice zmian organizacji i zasad działania Trybunału Konstytucyjnego. Warszawa 2017.

Sadurski, W. (2019). Poland's Constitutional Breakdown. Oxford.

Sokolewicz, W. (2006). Status prawny sędziego Trybunału Konstytucyjnego, [w:] M. Zubik (red.), Księga XX-lecia orzecznictwa Trybunału Konstytucyjnego. Warszawa.

Sokolewicz, W., Zubik, M. (2016). Uwaga 11 do art. 2, [w:] L. Garlicki (red.), Konstytucja Rzeczypospolitej Polskiej. Komentarz. Tom 1. Warszawa: 251-252.

Wojtyczek, K. (2018). Zadośćuczynienie za szkodę niemajątkową wyrządzona przez władzę publiczna. Uwagi na tle Europejskiej Konwencji Praw Człowieka. Państwo i Prawo 73(8): 3-19.

Wronkowska, S. (2018). O swoistości wykładni konstytucji. Uwagi kolejne. Przegląd Konstytucyjny $1: 12-25$.

Wronkowska, S., Hermann, M. (2015). Problematyka intertemporalna prawa konstytucyjnego. Zagadnienia podstawowe, [w:] J. Mikołajewicz (red.), Problematyka intertemporalna w prawie. Zagadnienia podstawowe. Rozstrzygnięcia intertemporalne. Geneza i funkcje. Warszawa: 195-241.

Zieliński, M. (2017). Wykładnia prawa. Zasady - reguły - wskazówki. Warszawa.

Ziółkowski, M. (2015). Standard legalności ustawy w orzecznictwie konstytucyjnym, [w:] P. Radziewicz (red.), Kontrola legalności ustawy w Sejmie. Warszawa: 239-295.

Ziółkowski, M. (2016). Komentarz do postanowienia z dnia 17 lipca 2003 r., K 13/02 (niedopuszczalność wznowienia postępowania przed Trybunałem Konstytucyjnym), [w:] L. Garlicki, M. Wiącek, M. Derlatka (red.), Orzecznictwo Trybunału Konstytucyjnego. Księga XXX-lecia. Warszawa: 471-489.

Ziółkowski, M. (2017). Odpowiedzialność odszkodowawcza za niezgodne z prawem działanie organów władzy publicznej w świetle Konstytucji RP. Niepublikowana rozprawa doktorska znajdujacca się w repozytorium INP PAN. Warszawa.

Ziółkowski, M. (2018). Zmiany składu orzekającego Trybunału Konstytucyjnego, [w:] K. Łakomiec (red.), Funkcjonowanie Trybunału Konstytucyjnego w latach 2014-2017. Raport Zespołu Ekspertów Prawnych Fundacji im. Stefana Batorego. Warszawa: 107-139.

Ziółkowski, M. (2019). Przywracanie praworządności w TK po kryzysie konstytucyjnym: wybór i powołanie Prezesa TK (analiza sporządzona dla Archiwum Osiatyńskiego). Warszawa. 


\section{THE RULES OF ASSIGNING JUDGES TO JUDICIAL PANELS OF THE CONSTITUTIONAL TRIBUNAL AND THE CONSEQUENCES OF VIOLATIONS OF THESE RULES}

\section{$\mathrm{Su} \mathrm{m} \mathrm{m}$ a r y}

The article disuses arguments against the unlimited power of the President of the Polish Constitutional Tribunal to assign and re-assign judges to Tribunal's panels hearing particular cases. It argues that this power should be exercised in accordance with the strict and plain meaning of the statutory provisions. The President should fully respect constitutional principles of legality, judges' impartiality as well as the efficiency of Tribunal's work. Criticising the President's latest practice, the article argues that the membership of the panels should be relatively invariable. The President should be allowed to change the membership in limited statutory circumstances only. Moreover, he or she should always assign judges, including the chairman of the panel and the judge-rapporteur, in alphabetical order. The President should also be absolutely bound by the order and subject-matter of cases to be heard by the Tribunal. The article discusses cases of abuses of the President's power to assign judges to the panels. The currently binding constitution and statutes do not directly provide any remedies for such presidential abuses. They can be considered unlawful in theoretical terms only. However, these abuses do not automatically make the Tribunal's judgement unlawful or invalid. The article provides an explanation for this duality of consequences from a theoretical and doctrinal perspective. Taking into account Article 77 of the Constitution, it also calls upon individuals to bring action for damages against unlawful abuses of the President's power.

Keywords: Constitutional Tribunal; judicial panel; abuses of power; judges' impartiality; invalidation of judgements; liability for damages 
